\title{
A LETHAL LEGAL EDUCATION: A CASE STUDY PROPOSAL
}

\section{PERRY SPANN}

\begin{abstract}
:
In the 1930s, the United States was a global leader in public education by having the largest student populations in the world attend high schools. In the 1980s, mass school shootings started escalating in the United States, as did profitable investing in the privatization of American prisons, which currently contain half of the world's total prison population. In the 2000s, adversarial laws related constitutionality and impartiality but not resolve for why the United States is where the majority of the world's prison population resides and massive school shootings. There has been debate of whether a correlation authentically or unexpectedly exists. There has been debate of why random mass school shootings cannot be predetermined by traditional means of profiling or quasi-experimental research, which ironically are two predispositions debated as contributing to high imprisonment in America. There has been debate that penal populations and school massacres may decrease if judicial practices are less politicized, popularized, and localized. While well intended, the decades of debates distract from definite resolve. The American dream of equal access to education in the pursuit of liberty and happiness is a civil right in a nation of exceptionally high imprisonment and indiscriminate school massacres. Resident and nonresident aliens in the United States are not the primary populations of prisoners because native-born citizens conduct the majority of crimes and school massacres in America. Disadvantaged individuals who are young, poor, minorities, and uneducated immensely compile prison populations in the United States. However, in American school massacres, disadvantaged or advantaged individuals who are young, poor, wealthy, or minorities can equally and effortlessly become defenseless instructors, deceased principals, injured professors, or dead students. The contrast is alarming. A proposed solution to help foster safeness and preparation for mass school shootings is that the United States Department of Education forms a sector enacting and regulating federal laws of defensive mandatory practices, which expands federal authority in state jurisdictions. The United States Department of Education administrates legal policies for schools through federal delegation. State governments chiefly regulate schools' safety. The proposal merits substantial review, as federal administrative laws are a necessity in the governance of education. If opposition exists to the proposal, consider the fact that from the time the proposal was written to the time the proposal is published and read, another mass school shooting likely occurred in the United States.
\end{abstract}

\section{Keywords:}

School shootings; education law; administrative law; mass shootings; the United States; global incarceration; public education; school massacres; school laws; American schools

JEL Classification: K39, 128, K23

\section{Authors:}

PERRY SPANN, The American Literary Society for Higher Education, United States, Email: perryphd@hotmail.com 


\section{Citation:}

PERRY SPANN (2018). A Lethal Legal Education: A Case Study Proposal . International Journal of Teaching and Education, Vol. VI(1), pp. 36-50., 10.20472/TE.2018.6.1.003 


\section{Introduction: The Deadly Denotative Purpose}

\section{Under the Gun: Global Leadership}

Mass school shootings in America exceed any other country. While other countries have experienced school shootings, none have been as detrimental or lethal as the massacres of students and teachers in schools in the United States. The fact that America leads as a nation of high prison incarceration, high gun ownership, and of high mass school shootings is despondent (see Figure 1). Both problems remain unsolved, but the problem of mass school shootings is feasible to reduce through strategic planning and implementation of administrative laws nationally.

The denotative meaning of a school in any collegiate dictionary is characteristically a building where teachers instruct students. Conversely, an American school can be synonymous with many issues, such as drugs, bullying, revenge, and recently, mass shootings (Ochberg, 2012). There have been assumptions that the massacres in schools are more prevalent in America than other countries for due to gun laws or parental negligence or mediated communication.

The reasons are genuinely unknown in definite manner that can cause resolve because a noteworthy pattern of school massacres in the United States is that they are unique in being:

- Random

- Varied

- Planned

- Gory

- Popularized

- Conveyed

- Located

There is not a definite way to track the trends of school massacres in America because the type of violence is difficult to project. Mass shootings are incidents where perpetrators or a perpetrator kills multiple people in public places indiscriminately and not with distinct means, such as a robbery (Congressional Research Service, 2013). Definitions of mass shootings vary based on specific conceptualizations of the term, but the fact that masses of people die is a commonality, and the fact that the reason is indistinct is a commonality. Schools have become a dominant location for mass shootings in the United States, which is a significant problem because the victims are typically youth and adults not prepared to counter the perpetrator or perpetrators. 


\begin{tabular}{|c|c|c|c|c|c|c|c|c|c|}
\hline Country & $\begin{array}{l}\text { Firearm } \\
\text { Homicide } \\
\text { Rate }\end{array}$ & $\begin{array}{l}\text { Non- } \\
\text { Firearm } \\
\text { Homicide } \\
\text { Rate }\end{array}$ & $\begin{array}{l}\text { Total } \\
\text { Homicide } \\
\text { Rate }\end{array}$ & $\begin{array}{l}\text { Firearm } \\
\text { Suicide } \\
\text { Rate }\end{array}$ & $\begin{array}{l}\text { Non- } \\
\text { Firearm } \\
\text { Suicide } \\
\text { Rate }\end{array}$ & $\begin{array}{l}\text { Total } \\
\text { Suicide } \\
\text { Rate }\end{array}$ & $\begin{array}{l}\text { Unintentional } \\
\text { Firearm nate } \\
\text { Death Rate }\end{array}$ & $\begin{array}{l}\text { Undetermined } \\
\text { Firearm Death } \\
\text { Rate }\end{array}$ & $\begin{array}{l}\text { Total } \\
\text { Firearm } \\
\text { Death } \\
\text { Rate }\end{array}$ \\
\hline Australia & 0.2 & 0.9 & 1.1 & 0.8 & 10.2 & 11.0 & 0.0 & 0.1 & 1.0 \\
\hline Austria & 0.2 & 0.4 & 0.5 & 2.7 & 12.4 & 15.1 & 0.0 & 0.1 & 3.0 \\
\hline Belgium & 0.3 & 0.7 & 1.1 & 1.3 & 17.1 & 18.4 & 0.0 & 0.1 & 1.8 \\
\hline Canada & 0.5 & 1.0 & 1.5 & 1.7 & 9.9 & 11.6 & 0.0 & 0.0 & 2.3 \\
\hline $\begin{array}{l}\text { Czech } \\
\text { Republic }\end{array}$ & 0.1 & 2.4 & 2.6 & 1.4 & 11.2 & 12.5 & 0.1 & 0.2 & 1.8 \\
\hline Denmark & 0.2 & 0.6 & 0.8 & 1.3 & 8.8 & 10.1 & 0.0 & 0.0 & 1.6 \\
\hline Finland & 0.3 & 1.6 & 1.9 & 3.3 & 14.5 & 17.8 & 0.0 & 0.0 & 3.6 \\
\hline France & 0.2 & 0.4 & 0.6 & 2.2 & 14.3 & 16.5 & 0.1 & 0.3 & 2.8 \\
\hline Germany & 0.1 & 0.5 & 0.6 & 0.9 & 11.3 & 12.3 & 0.0 & 0.1 & 1.1 \\
\hline Hungary & 0.1 & 1.4 & 1.5 & 0.8 & 24.1 & 24.9 & 0.0 & 0.0 & 0.9 \\
\hline Ireland & 0.4 & 0.5 & 0.8 & 0.5 & 10.1 & 10.7 & 0.0 & 0.1 & 1.0 \\
\hline Italy & 0.3 & 0.4 & 0.8 & 0.9 & 5.7 & 6.6 & 0.1 & 0.0 & 1.3 \\
\hline Japan & 0.0 & 0.3 & 0.3 & 0.0 & 23.1 & 23.1 & 0.0 & 0.0 & 0.0 \\
\hline Netherlands & 0.2 & 0.7 & 0.9 & 0.2 & 9.4 & 9.7 & 0.0 & 0.0 & 0.5 \\
\hline $\begin{array}{l}\text { New } \\
\text { Zealand }\end{array}$ & 0.2 & 1.1 & 1.2 & 1.0 & 11.3 & 12.3 & 0.0 & 0.0 & 1.2 \\
\hline Norway & 0.0 & 0.6 & 0.7 & 1.7 & 9.5 & 11.2 & 0.0 & 0.0 & 1.8 \\
\hline Portugal & 0.5 & 0.5 & 1.0 & 1.1 & 9.3 & 10.4 & 0.0 & 0.2 & 1.8 \\
\hline $\begin{array}{l}\text { Republic of } \\
\text { Korea }\end{array}$ & 0.0 & 1.3 & 1.3 & 0.0 & 31.5 & 31.5 & 0.0 & 0.0 & 0.0 \\
\hline Slovakia & 0.2 & 1.0 & 1.2 & 0.9 & 10.8 & 11.7 & 0.4 & 0.2 & 1.8 \\
\hline Spain & 0.1 & 0.6 & 0.7 & 0.4 & 6.4 & 6.9 & 0.1 & 0.0 & 0.6 \\
\hline Sweden & 0.2 & 0.7 & 0.9 & 1.2 & 11.0 & 12.2 & 0.1 & 0.0 & 1.5 \\
\hline $\begin{array}{l}\text { United } \\
\text { Kingdom }\end{array}$ & 0.0 & 0.3 & 0.3 & 0.2 & 6.6 & 6.8 & 0.0 & 0.0 & 0.2 \\
\hline $\begin{array}{l}\text { United } \\
\text { States }\end{array}$ & 3.6 & 1.7 & 5.3 & 6.3 & 6.1 & 12.4 & 0.2 & 0.1 & 10.2 \\
\hline
\end{tabular}

Figure 2. Adapted from "Total Death Rates per 1000,000 Population by Non-US High Income Countries," by Erin Grinshteyn and David Hemenway, 2010. Copyright by The American Journal of Medicine.

There may be explicit ways to help counter the massacres or to be prepared for the massacres, but national assistance may be best to have effective uniformity in schools. If it is better to be prepared than to have to get prepared, then preparation needs to occur rapidly in America. Currently, security is localized and of disparities among different jurisdictions, boroughs, districts, and parishes in the United States. There is a lack of uniformity in securing equitable safeness against mass shootings in schools.

\section{An Exception to the Rule: Clarity of the Rarity}

The fact that mass school shootings are a rarity in America compared to deaths of children by automobile accidents or accidental deaths does not diminish the problem. There is a rational risk associated with automobile accidents when operating motor vehicles. There is not a rational risk associated with attending schools to learn. Mass school shootings are unexpected in a safe location where the purpose is to learn. Even one child dying from a shooting in a school is too many when the reasoning is ambiguous, and the purpose 
schools serve is teaching students to learn. When the purpose is disrupted with the fear of safety not being satisfactory, learning can be impeded.

The purpose of a school equates a low risk for violence to many Americans, but the massacres in American schools exceed other countries if compared on a global scale. In the United States, there have now been at least 100 school massacres in three decades (Plumer, 2012). The number is excessive when considering how mass school shootings occurred previously, which is in clusters. School shootings inspire 0.22 other school shootings, and each mass shooting inspires 0.3 additional mass shootings, which means that not every mass shooting will lead to another, but for every five school shootings, one is inspired by a past school shooting (Pappas, 2015). The basic purpose of schools in America seems eroded with a feasibility of mass rampaging gun violence.

Parents of children killed in school massacres likely do not think the shootings are rare in America or as futile as some researchers promote. Instructors may not think mass school shootings are minor when considering a career or as faculty in the profession. The facts may be authentic, but so is the reality that the problem is not solved and not of abundant deterrent measures. Mass school shootings can lead to problems increasing or existing that impact the quality of learning in the United States. One problem is the impact of teachers feeling safe when instructing in schools, which is an area of great concern considering the United States has a shortage of qualified and proficient teachers.

The United States is a tragic exception when examining global school violence, and in a cross-national study of 171 countries, the conclusion is the United States may be particularly susceptible to future public mass shootings (Lankford, 2016). The reason is that nations of high firearm access and ownership have challenges, legally, in preventing public shootings. Legally, American schools should be prepared for the possibility of future school massacres. If history teaches good lessons, the problem of mass school shootings in the United States may not be easily solved but may decrease if national administrative laws or policies exist requiring preventative measures.

\section{Literature Review: Storytelling Time through the Obituaries}

\section{Dead Wrong: The History of Mass School Shootings in America}

There are obituaries dating to the $18^{\text {th }}$ century of children killed in a school massacre in America (Dixon, 2005). School massacres in the United States are not a modern problem. The contemporary issue is school massacres are excessive in the United States. Historically, mass murder is not a unique phenomenon, yet the escalation of massive children being killed while at schools is a unique phenomenon because the massacres increased significantly in the early 1980s to early 1990's. The mass school shootings occurred in primary, secondary, and post secondary academic institutions.

While not all attempts have been successful, too many resulted in massive deaths (see Figure 2). Previous research and investigations of the reasons for the mass school shootings and the occurrences have not resulted in resolutions for the problem. 
The deadliest mass shootings in U.S. history

\begin{tabular}{|c|c|c|c|}
\hline $\begin{array}{l}49 \text { killed } \\
\text { JUNE 12TH, } 2016 \\
\text { Pulse nightclub } \\
\text { Orlando, FL }\end{array}$ & $\begin{array}{l}32 \text { killed } \\
\text { APRIL 16TH, } 2007 \\
\text { Virginia Tech } \\
\text { Blacksburg, VA }\end{array}$ & $\begin{array}{l}27 \text { killed } \\
\text { DECEMBER 14TH, } 2012 \\
\text { Sandy Hook Elementary } \\
\text { Newtown, CT }\end{array}$ & $\begin{array}{l}23 \text { killed } \\
\text { OctoBER 16TH, } 1991 \\
\text { Lubys Cafeteria } \\
\text { Killeen, TX }\end{array}$ \\
\hline 5 & 6. & 7. & 8. \\
\hline $\begin{array}{l}21 \text { killed } \\
\text { JULY 18TH, } 1984 \\
\text { MCDDalds } \\
\text { San Ysidro, CA }\end{array}$ & $\begin{array}{l}18 \text { killed } \\
\text { AUGusT 1ST, } 1966 \\
\text { University of Texas } \\
\text { Austin, TX }\end{array}$ & $\begin{array}{l}14 \text { killed } \\
\text { DECEMBER 2, 2015 } \\
\text { Inland Regional Center } \\
\text { San Bernardino, CA }\end{array}$ & $\begin{array}{l}14 \text { killed } \\
\text { AUGuST 20TH, } 1986 \\
\text { Edmond Post Office } \\
\text { Edmond, OK }\end{array}$ \\
\hline
\end{tabular}

Figure 2. Adapted from "Deadliest Mass Shootings in US History Fast Facts," 2017. Copyright by the Cable News Network.

An example is that since 2013, over 233 school shootings occurred, and mass school shootings were labeled as becoming the 'norm' in the United States (Fantz, 2014). There is nothing normal about children sitting in classrooms and being shot by random gunfire. Fatal and nonfatal injuries resulted from a history of mass school shootings in the United States.

\section{Perception is not Reality: Administrative Education Laws}

There is an interesting parallel between the United States globally leading in schools massacres and incarceration, in particular if noting the increase of privatized prisons and high stock purchases of guns (see Figure 3). Private prisons being built and funded increased during the elevation of incarceration and mass shooting in the United States.

\section{Majority of gun owners own multiple guns}

$\%$ of gun owners saying they own ...

\begin{tabular}{|c|c|c|}
\hline \multirow[b]{2}{*}{$\begin{array}{c}\text { One gun } \\
32 \%\end{array}$} & \multicolumn{2}{|c|}{ More than one gun $66 \%$} \\
\hline & $\begin{array}{c}2-4 \text { guns } \\
(37 \%)\end{array}$ & $\begin{array}{c}5+\text { guns } \\
(29 \%)\end{array}$ \\
\hline \multicolumn{3}{|c|}{$\begin{array}{l}\text { Note: Share of respondents who didn't offer an answer not shown. } \\
\text { Source: Survey of U.S. adults conducted March } 13-27 \text { and April 4- } \\
\text { 18, } 2017 \text {. } \\
\text { "America's Complex Relationship With Guns" }\end{array}$} \\
\hline \multicolumn{3}{|c|}{ PEW RESEARCH CENTER } \\
\hline
\end{tabular}


Figure 3. Adapted from "America's Complex Relationship with Guns," by Kim Parker, Juliana Horowitz, Ruth Igielnik, Baxter Oliphant, and Anna Brown, 2017. Copyright by the Pew Research Center.

The increase may cause inquiry of judicial practices and laws in the United States. The laws being strict, effectual, adaptive, or practical may be doubted because schools are the second most dangerous location for mass shootings in the United States. An important fact to consider is school violence is a broad category that differs from mass school shootings, such as massacres or gang violence. School violence can comprise fights or incidents with knives.

Mass school shootings in public have escalated in America. Mass school shootings in schools escalated in America. The history of mass shootings in public schools contains accounts of gruesome mass murders, so the perception that school violence has always been a problem is not the reality of mass shootings in schools. Mass school shootings have been random but increasing in American schools.

The perception may be that the laws in the United States are not benefitting students at schools by making safety a principal concern. However, efforts and laws that largely regard school safeness are enacted on a state level and observed on a federal level. The United States Department of Education administrates legal regulations and policies for American schools. Laws are regulated and maintained by the United States Department of Education. The United States Department of Education (2017) has, "the mission to promote student achievement and preparation for global competitiveness by fostering educational excellence and ensuring equal access." The United States Department of Education has four sectors well known, which are student loans, grants and programs, laws and guidance, and data and research.

\section{A Department Divided: Good Intentions, Unforeseen Consequences}

There are four divisions of regulation for public schools in the United States. The United States Department of Education regulates student loans, grants, laws and guidance, and data relative to schools. The history of safety acts or provisional options for states recommended by the federal government may seem trite since examining the chronicle of school shootings and school massacres in the United States. The United States government has made great efforts to mandate gun violence and shootings at schools through national legislation, such as:

The Crime Control Act of 1990

Gun-Free Schools Act of 1990

Safe and Drug-Free School and Communities Act of 2004

Elementary and Secondary Education Act of 1965

No Child Left Behind Act of 2001

Non-Regulatory Guidance for Unsafe School Choice Option

National Defense Authorization Act in 2017

\section{When History Repeats Itself: National Acts Delegated}


Within the well known four sectors at the United States Department of Education, the sector of laws and guidance addresses school safety as part of the Elementary and Secondary Education Act of 1965. In May 2004, the act, No Child Left Behind, implemented NonRegulatory Guidance for Unsafe School Choice Option. The option, which is of Section 9532 of the Elementary and Secondary Education Act of 1965 indicated:

States obtaining funds under the act establish and implement a statewide policy requiring that students attending persistently dangerous public schools or students who are victims of violent criminal offenses while attending a public school, be allowed to attend a safe school. (United States Department of Education, 2017)

States were strongly encouraged to define persistently dangerous schools on a local level of incidents per school. Logistically, any school may not seem safe in the United States if examining the history of mass school shootings or current risk of mass shootings occurring at schools. While the intent of the act was fundamental to address juvenile delinquent conduct, the fact is that students have entered schools perceived as safe and persistently dangerous with guns and not been detected until the shooting occurs.

The Secondary Education Act of 1965, as amended by the Every Student Succeeds Act on December 10, 2015, and the National Defense Authorization Act in 2017, 129 Statute 1802 incorporates safety as a national facet of school in America (United States Department of Education, 2017). In the Every Student Succeeds Act, Title IV-21 ${ }^{\text {st }}$ Century Schools was revised in 2017, and the revision eliminated Part A of Title IV that focused on safe and drug free schools and communities except for the General Provisions (7101), Section 4001, which contains Activities to Support Safe and Healthy Students (7118) in Section 4108.

In Every Student Succeeds Act of 2015, Part A, Student Support and Academic Enrichment Grants is void of Subpart 2, National Programs (\$§4121-4130) that implemented Subpart 3-Gun Possession, which was transferred to Title VIII-F-4. Subpart 3-Gun Possession incorporates Section 8561, Gun-free requirements. Subpart 4-Subpart 3-National Activities for School Safety (7281), Section 4631, does not have a provision for concealed weaponry or preventative measures and training for school shootings that is mandatory in every state in America.

\section{The Short End of the Stick: Teacher Shortages in America}

Teachers are one of the most valuable resources in the world and whom the majority of youth spend time with during their lives. Youth are typically in educational institutions at least eight hours daily except during academic recesses. Teachers may not feel comfortable instructing students when examining the trend of mass shootings in schools. The discomfort can cause a significant decline in the quality of teachers and in the abundance of teachers, which is an area consistently and historically challenging to increase in America. The United States Department of Education Office of Postsecondary 
Education has published since 1991 a report of teacher shortages nationwide. To recruit and retain good educators, safety must be a priority to counter the fear of mass shootings.

Teachers in the United States typically do not earn high salaries, have considerable documentation to complete throughout the academic calendar year, and are challenged with fulfilling state credentials to work. Previous school shootings are not enticements for projected teachers. "Solving the Teacher Shortage: How to Attract and Retain Excellent Educators" reported:

One of the most pressing issues facing policymakers is how to staff classrooms with a stable teaching workforce responsive to complex student needs and the growing demands of the knowledge economy. Recurrent teacher shortages are a function of both declines in entrants to teaching and high rates of teacher turnover, especially in low-income schools. This turnover is costly, and undermines student achievement and school improvement efforts.

(Podolsky, Kini, Bishop, Darling-Hammond, 2017, para. 1)

California, as an example, issued over 10, 000 intern credential, permits, and waivers to obtain teachers who did not complete the preparation programs to resolve the urging problem of having a shortage of teachers last year (Learning Policy Institute, 2017). Substandard teaching preparation in the United States is a common concern in recent years, and often teachers are hired on provisional status (Figure 4). California is not the only state with a deficiency of teachers, as urban areas or inner city schools struggle to maintain teachers in many states such as Illinois, Chicago, Florida, and New York. "A Coming Crisis in Teaching? Teacher Supply, Demand, and Shortages in the U.S." reported:

Widespread media reports of local teacher shortages have become topic in education since the summer of 2015. After years of teacher districts began hiring again as the economy recovered Recession. Many were surprised to find they had serious difficulty finding qualified teachers for their positions, especially in fields like mathematics, science, special education, and bilingual education/English language development. An umber of states greatly expanded emergency permits to allow hiring of untrained teachers to meet these demands-which is the classic definition of shortage. (Sutcher, Darling-Hammond, Carver-Thomas, 2016)

Increased federal legislation in the United States may be necessary to create consistent safeguarded schools equally protected that attract educators. The increase in safeness may positively impact teacher recruitment, but even if the increase does not have a positive impact, a decrease certainly will have a negative impact on how current teachers assess safeness in schools. In conclusion, supplemental research to learn if teachers would prefer local or federal legislation to provide safety for schools may be necessary. 
Substandard Credentials and Permits Doubled Between 2012-13 and 2015-16

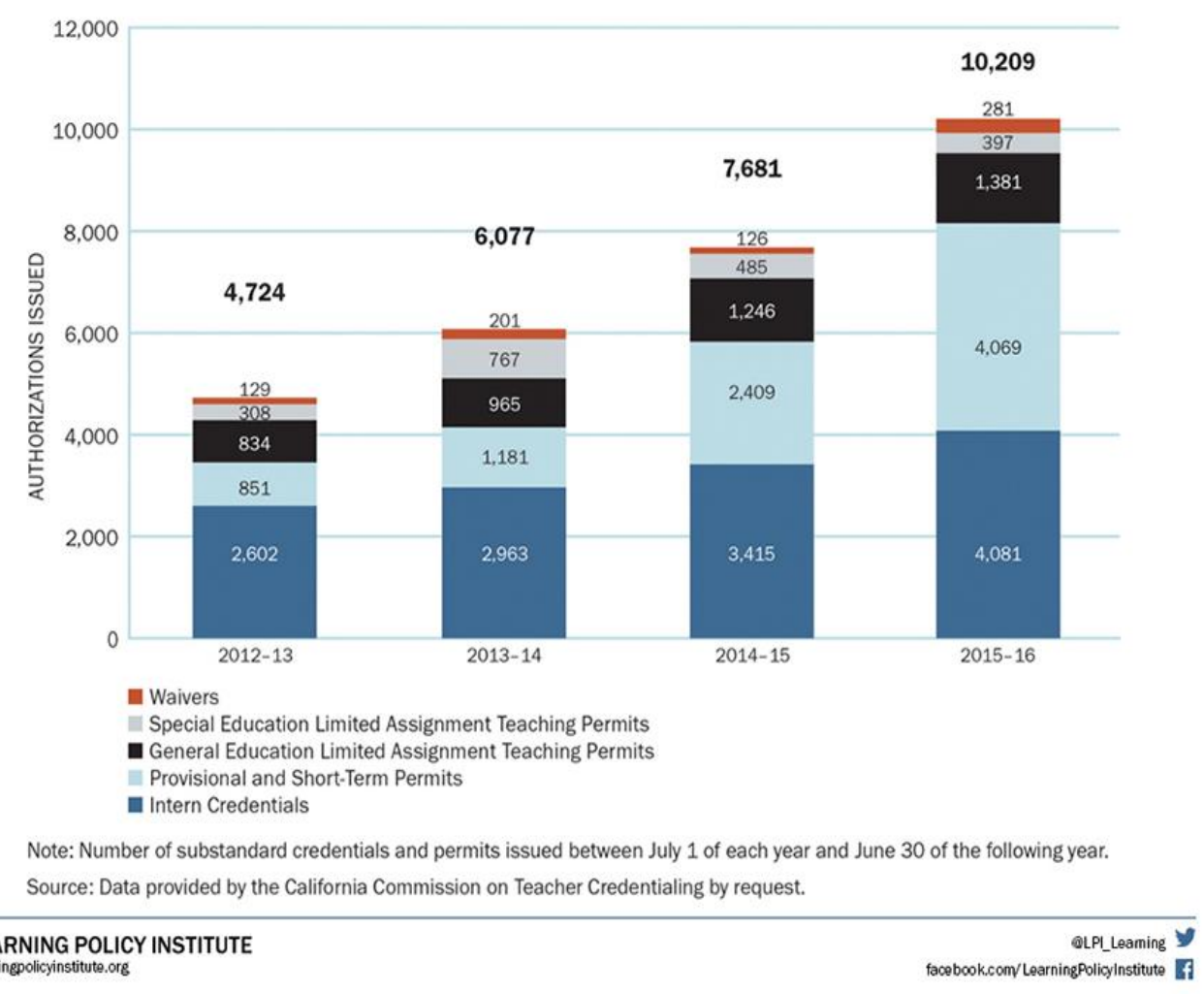

Figure 4. Adapted from "California Teacher Workforce Trends Signal Worsening Shortages," 2017. Copyright by the Learning Policy Institute.

\section{' $G$ ' is for Gun: State Laws of Safeness in Schools}

The first law in the United States enacted that authorized teachers to carry guns to schools was in South Dakota amid national debates to enhance securing schools (Eligon, 2013). The decision for teachers to be permitted to carry guns is a state allowance and not a national pronouncement. Some states' legislators debated enacting laws for having trained officers carry firearms but not individuals who are not of law enforcement. Some state legislators debated laws for teachers and all school staff to carry concealed weapons to schools, though the Second Amendment to the United States Constitution protected the right to possess firearms if not relative to a militia and for lawful reasons of self-defense.

The types of guns permitted vary, which further causes disconformity. Reasonably, individuals should be assessed if carrying concealed weapons to schools, and the assessment should be national since state assessments can diverge in composition by jurisdictions or school districts, which further causes a lack of consistency. The funding associated with schools resources for mass shooting safeness is a concern, as poor areas of schools may not have funding to increase, maintain, or implement safety programs focused sole are preventative measures during mass shootings. 
As of 2017 , at least twenty states, which is a third of the Untied States, permit adults to carry firearms on to schools with specific permissions to attempt to promote school security, which equates at least 23,000 schools have armed security or armed staff (Chiaramonte, 2017). Although the adults may have proper training to carry and use firearms, there have been deadly school shootings with armed resource officers on the premise of the academic institutions. The fact is that preventing violence from entering schools is challenging, but should be researched to learn how the prevention can occur and what measures to use (Flannery, 2015). Arming faculty and staff with guns is one measure depending on the state's laws, but the effectiveness remains contentious as protection.

\section{Getting Schooled: Community Impacts of School Shootings}

Historically, the shootings have a major impact on local communities. Some communities had elevations in psychological treatment for youth or educators. Some communities experienced declines in attaining educators or administrators for schools. Some communities responded with local defense increasing at schools through metal detectors. However, most American schools are not well protected with guarded gates, police, cameras, fences, resource officers, or monitoring systems. Schools in the United States typically are congenial in culture and environment, which is a lenient target if seeking victims.

The United States Department of Education may enhance safety in schools by implementing a sector sole for school safety. The sector could regulate laws, nationally, for schools in the United States to have cohesive practices of security and defensive training measures. The perimeters of schools can benefit from increased security at entry points, and mandatory trainings for defense can benefit students, teachers, and staff. The implementation should be cohesive to have equitable governance of educational facilities. As of 2017 , states' laws regulate school security, but the regulations vary and are not consistent.

Consistent regulations can help monitor the problem of school shootings and massacres, plan preventative procedures, and create improved uniformity in noting counters that are or are not effective with reasoning that may help explain disparities or continuities. Traditionally, the federal function in education is limited in the United States. The Tenth Amendment of the United States Constitution defines interests between federal and state governments, permits education policies to be decided and enacted at the state and local levels (United States Department of Education, 2017). A proposal for a revision of the federal limitation regarding schools' safeness is valid given the merit of substantiated deaths due to mass school shootings.

\section{Methodology: Those Who Teach}

\section{Overview: Its Own Merits}

The global excessiveness of school shootings in the United States may merit increased federal regulation to enhance security measures for all schools. 


\section{Objectives: Safety First}

1. The objective is to learn if current teachers prefer local or federal legislation to secure safeness in schools.

2. The objective is to learn if teachers do not care whether states' government or federal government regulates school safety.

\section{Research Methodology: An Ample Sample}

The research methodology used for the study was surveying from a random population of educators. Surveys are common applications to collect data from a sample population when seeking descriptive research. The descriptive research methodology permits direct inquiry focused on the topic researched. The instrumentation applied was questionnaires. The questionnaires were selected to offer exact opinions to obtain clear data for the study.

\section{Sample Population: Size Does Matter}

The methodology for this study was a random sample of educators as the target population in the United States of America who currently instruct classes on physical campuses or physically in schools. There are 7.2 million educators in the United States according to the United States Census Bureau of Labor Statistics (2009). The use of random sampling was to attempt to obtain a representative sample. The selection of the target population was critical to satisfying the purpose of the questionnaire executed. The sampling was applied to have proportionate results as much as feasible that can be, if elected, compared and contrasted to have meaningful feedback.

The questionnaire was geographically distributed randomly throughout the United States using mediated communication to a population of educators who varied by age, race, gender, status, sexual orientation, geography, and culture. The determining number of the sample size was the goal of 100 because the population of educations is near 10 million, and the margin of error statistically is $10 \%$. The required sample size, with the estimated prevalence of the variable of interest, and margin of random errors were used in the determination of the population number. The probability approach of random sampling was effectively applied.

\section{Instrumentation: Not Playing Around}

The questionnaires were electronic and closed ended. Materials were email and electronic devices accessible to email, so the equipment was minimal. The questions were selfadministered, which evolved into being group administered due to response rates and voluntary participation. The questionnaire asked if school safety should be the responsibility of the states' governments or the federal government. The questionnaire included a disclosure to consent clause for participation.

\section{Procedure of Data Collection: It's in the Mail}


The questionnaires were emailed, and respondents sent replies of the questionnaires completed via email. The email responses were categorized according to the results to have a final accumulation of the preferences indicated by the sampling population. The responses were structured, fixed, and lucid.

\section{Findings: What's Safe to Say}

The results were that $80 \%$ support school safety being the responsibility of federal government. $12 \%$ did not care, and $6 \%$ supported school safety being the responsibility of the states' governments. $2 \%$ indicated being undecided or did not know what to select.

\section{Data Propositions: Chance Does Favor the Prepared Mind}

\section{Analysis: When Opportunity Knocks}

The best opportunity to have uniformity for safe school preventative measures from mass shootings may be via federal legislation. When states' schools have a lack of unification in policies, procured, techniques, or methods, the educational system in the United States is impacted. The intent to have safe schools must be a priority, as an average of two shootings a month for three years is domestically and globally excessive when examining the basic purpose of academic institutions. Students often have easy access to firearms, yet guns are easy to access for individuals in America. Therefore, the monitoring of students and other perpetrators trying to enter school grounds with weapons may be best through security measures.

The concept of arming instructors, faculty, or staff at schools is a dangerous and precautious venture. Training and standardization are concerns when states' governments along with possible injuries that can occur if the guns are mishandled or accidentally disarm. Incidents occurred at schools in Utah and Idaho recently of accidental shootings by teachers permitted to carry concealed weapons to schools. The need for safeness from mass shootings in schools requires thorough study of the best ways to resolve the problem. Federal regulations should incorporate safeness that implements protection for various situations of mass shooters using funding resources to conduct in-depth research qualitatively.

\section{Suggestions: Safeness in Schools}

The United States Department of Education may improve safeness in schools by forming a sector that enacts and regulates laws to:

1. Administer funding equally to schools for safety regulations to be implemented

3. Provide equivalent safety measures, procedures, and resources for schools

3. Institute training programs preparing for mass school shootings

4. Decrease federal funding for schools noncompliant or issue fines 


\section{Conclusion: Not Dead and Buried}

In the United States, earning an education is a civil right. The issue of mass shootings remains unresolved and seems revisited each time an incident occurs reminding how the problem impedes learning safely in schools. While many youth, teachers, and staff are departed due to mass shootings at schools, the problem remains current. In the United States, mass shootings in schools are exceeding, and the United States has the highest incidents of 233 countries. Mass school shootings warrant federal investigation and legislation to have definite resolve in attempting proactive and preventive measures to counter perpetuators and to prepare properly for perpetrators. Federal legislation should occur that consistently helps to foster decreasing mass shootings in schools and increasing the safety in schools.

\section{References}

Azreal, D., Coen, A., Lord, A, and Miller, M. (2014). Are Mass Public Shootings Increasing? Evidence of a recent shift in an underlying process. Northwestern University. Retrieved from https://www.northeastern.edu/rise/presentations/the-trends-in-mass- public-shootings-from1980-2016/

Bishop, J., Darling-Hammond, L., Kini, T., and Podolsky, A. (2017). Solving the teacher shortage: How to attract and retain excellent teachers. Learning Policy Institute. Retrieved from https://learningpolicyinstitute.org/product/solving-teacher-shortage

Brown, A, Horowitz, J., Igielnik, R. Oilphant, B. and Parker, K. (2017). America's complex relationship with guns. Pew Research Center.

Carver-Thomas, D., Darling-Hammond, L., and Sutcher, L. (2016, September 15). A coming crisis in teaching? Teacher supply, demand, and shortages in the U.S. https://learningpolicyinstitute.org/product/coming-crisis- teaching

Chiaramonte, P. (2017, June 28). Teachers packing heat: More educators taking gun training classes http://www.foxnews.com/us/2017/06/28/teachers-packing-heat-more- educators-taking-guntraining-classes.html

Congressional Research Service. (2013, March 18). Public mass shootings in the United States: Selected implications for federal public health and safety policy. Retrieved from https://fas.org/sgp/crs/misc/R43004.pdfDixon, D. (2005). Never come to peace again: Pontiac's uprising and the fate of the British empire in North America. Norman: University of Oklahoma Press, 2005.

Eligon, J. (2013, March 8). A state backs guns in class for teachers. http://www.nytimes.com/2013/03/09/us/south-dakota-gun-law- classrooms.html?_r=0

Everytown for Gun Safety Support Fund. (2017). 233 School shootings in $\quad$ America since 2013. Retrieved from https://everytownresearch.org/school-shootings/2897/ 
Fantz, A. (2014, June 19). A closer look: How many Newtown-like school shootings since Sandy Hook? Cable News Network. Retrieved from http://www.cnn.com/2014/06/11/us/school-shootings-cnn- number/index.html

Flannery, M. E. (2015, March 26). States look to throw open school doors to concealed weapons. Retrieved from http://neatoday.org/2015/03/26/states-look-to- throw-open-school-doorsto-concealed-weapons/

Fox, C., Harding, D., Mehta, J., Newman, K. and Roth, W. (2005). Rampage: The social roots of school shootings. Basic Books, New York.

Harvard School of Public Health. (2014). Mass shootings becoming more frequent. Retrieved from https://www.hsph.harvard.edu/news/hsph-in-the- news/mass-shootings-becoming-more-frequent/ Hemenway, D. and Grinshteyn, E. (2016). Total death rates per 100,000 population by Non-U.S. high income countries. The American Journal of Medicine.

Lankford, A. (2016). Public mass shooters and firearms: A cross-national study of 171 Countries. Violence and Victims, 31, 2, pp. 187-199. https://doi.org/10.1891/0886-6708.VV-D-15-00093

Learning Policy Institute. (2017). California teacher workforce Trends signal worsening shortages. Retrieved from https://learningpolicyinstitute.org/product/california-teacher-workforce- $\quad$ trendssignal-worsening-shortages-brief

Ochberg, F. (2012, February 28). Why does America lead the world in school shootings? Cable News Network. Retrieved from http://globalpublicsquare.blogs.cnn.com/2012/02/28/why-does-americalead-the-world-in-school-shootings/

Pappas, S. (2015, August 26). Why America is prone to mass shootings? Live Science. Retrieved from https://www.livescience.com/51991-why- america-is-prone-to-mass-shootings.html Plumer, B. (2012, December, 14). Why are mass shootings becoming more common? Retrieved from https://www.washingtonpost.com/news/wonk/wp/2012/12/14/whyare- mass-shootingsbecoming-more- frequent/?utm_term=.ad7fda713c29

Protecting our students and Teachers. (2017). School shootings. Retrieved from http://postky.org/shootings

Willingham, A. (2016, June 21). A visual guide: Mass shootings in America. $\quad$ Cable News Network. Retrieved from http:/www.cnn.com/2016/06/13/health/mass-shootings-in-america-in- chartsand-graphs-trnd/index.html

U.S. Census Bureau. (2011, June 27). Profile America facts for features. (Report No. CB11-FF.15). Retrieved from http://www.census.gov/library/publications/2015/demo/p70-140.html

United States Department of Education, National Center for Education Statistics. (2016). Digest

of education statistics, 2015. Retrieved from https://nces.ed.gov/fastfacts/display.asp?id=28

United States Department of Justice, Federal Bureau of Investigation. (2013). A study of active shooter incidents in the United States between 2000-2013. 